\title{
26485 - THE AMNESTIC AND SEDATIVE-HYPNOTIC PROPERTIES OF ETOMIDATE IN MICE CAN BE DISSOCIATED BASED ON GABA(A) RECEPTOR SUBTYPE PHARMACOLOGY.
}

\section{Beverley Orser PhD MD, Beverley Orser, MD PhD; Loren Martin, MSc; Victor Cheng, John MacDonald, PhD; Sunnybrook And Women's College HSC, Toronto, ONTARIO, Canada}

Introduction: Our aim is to elucidate the mechanisms underlying the amnestic properties of anesthetics. GABA(A) receptors containing the á;5 subunit (á;5GABA(A)Rs) are predominantly expressed in the hippocampus, a brain region that is critically involved in learning and memory. á;5GABA(A)Rs have been implicated in memory processes, as á;5 null mutant (á;5-/-) mice exhibit improved performance in certain hippocampaldependent learning tasks (J Neurosci 22(13):5572). Further, behavioral studies showed that á;5-/- mice are resistant to the amnestic effects of etomidate (Society for Neuroscience Abstracts, 2006: 611.11). The aim of this study was to determine whether á;5-/- mice exhibit a generalize insensitivity to etomidate by measuring sedation and hypnosis.

Methods: Experiments were approved by the local animal care committee. The sedativehypnotic properties of etomidate were tested in á;5+/+ and á;5-/- mice using the classical loss of righting reflex (LORR) paradigm. The LORR was measured for a wide range of etomidate doses $(5-15 \mathrm{mg} / \mathrm{kg})$. A quantal dose-response plot was constructed and fitted with a logistic equation. The time to LORR was also quantified. Experimenters were blinded to the mouse genotype.

Results: The dose of etomidate that caused half the maximal response was similar in WT and a; $5-/-$ mice ( 9.6 and $9.2 \mathrm{mg} / \mathrm{kg}, \mathrm{n}=35$ and $\mathrm{n}=34$ respectively, $\mathrm{P}>0.05$ ). The time to LORR also showed no difference between WT and á;5-/- mice.

Conclusions: Behavioral endpoints that are commonly used as surrogate measures for sedation and loss of consciousness were studied and showed that á;5-/- mice did not exhibit a non-specific generalized resistance to etomidate. Thus, á;5-/- mice exhibited reduced sensitivity for amnesia but not sedative-hypnotic effects indicating different components of the anesthetic state can be dissected based on GABA(A) receptor subtype. 